\title{
The determinants of consumer behaviour of students from Brno when purchasing organic food
}

\author{
Jana Švecová, ${ }^{1}$ Pavla Odehnalová ${ }^{2}$
}

\begin{abstract}
The subject of this paper is the analysis of consumer behaviour in the organic market, focused on the behavior of students from Brno. Our study brings information which can potentially be used for further research and will also be useful for organizations with a practical interest in the production sale and distribution of organic food. To investigate the influence of the various factors was used the extended model of Theory of Planned Behaviour (TPB). In the current concept, there is no research in the Czech Republic that would apply the approach of Yadav and Pathak (2016) to examine of consumer behaviour on the sample of students, i.e. young Czech generations who are a potential target group. The theoretical part deals with the concept of consumer behaviour, based on the findings of the latest studies, dealing with this topic. In the practical part, the own research is presented, realized on a sample of 403 young consumers, studying in the second largest city of the Czech Republic, the city of Brno. In the Czech Republic, the young consumer is influenced mainly by factors such as personal attitude and subjective norms. Limitations of this study are the fact that in our questionnaire we were interested in how the consumer viewed the purchase of organic food in general and not how they view the purchase of individual organic products and that the research may be limited by the fact that the questionnaire was aimed solely at the younger generation of consumers studying in Brno, the second largest city in the Czech Republic. The behaviour of the younger generation has received little investigation, and in the Czech Republic, there is a lack of research on the behaviour of this sector.
\end{abstract}

Key words: Consumer behaviour, organic food, theory of planned behaviour JEL Classification: M31, Q21, C1

Received: 10 October 2018 / Accepted: 12 March 2019/Sent for Publication: 18 March 2019

\footnotetext{
${ }^{1}$ Masaryk University, Faculty of Economics and Administration, Department of Corporate Economy, Brno, Czech Republic. Email: jana.svecova@mail.muni.cz

${ }^{2}$ Masaryk University, Faculty of Economics and Administration, Department of Corporate Economy, Brno, Czech Republic. Email: odehnalova@mail.muni.cz
}

(c) 2019 by the authors; licensee Review of Economic Perspectives / Národohospodářský obzor, Masaryk University, Faculty of Economics and Administration, Brno, Czech Republic. This article is an open access article distributed under the terms and conditions of the Creative Commons Attribution 3.0 license, Attribution - Non Commercial - No Derivatives. 


\section{Introduction}

Health and a healthy lifestyle have become increasingly important trends in recent times. Consumers have become increasingly interested in what they eat in particular, the nutritional value and the level of artificial additives in food. These changes in preferences have led to changes in consumer behaviour and significant growth in the demand for organic food (Šánová, 2008), which has become one of the fastest growing markets in the food industry (Hughner et al., 2007). According to FiBL (2016), this boom in organic food is set to continue and a recent report from the TechSci Research company gave a positive outlook for the future (TechSchi Research, 2015). In order to respond adequately to these changes, it is important to understand the factors influencing the behaviour of consumers when purchasing organic food, both for the retailer and producer, as well as for politicians involved in ecological farming (Zvěřinová, Urban, Št’astný, 2011).

When studying the current literature which examines consumer behaviour in the organic food market, we discover a number of studies that have been carried out in the USA as well as across the whole of Europe (e.g., Makatouni, 2002; Arvola et al., 2008; Ahmed and Rahman, 2015; Effendi et al., 2015; Suh, Eves and Lumbers, 2012). As regards the Czech Republic, only several empirical studies on organic food consumption has been carried out (e.g., Frýdlová and Vostrá, 2011; Zvěřinová, Urban and Ščastný, 2011; Urban, Zvěřinová and Št’astný, 2012; Živělová and Crhová, 2012; Zagata, 2012; Ščasný, Urban and Zvěřinová, 2013). This geographical gap in the research was one of the reasons for carrying out this research. In addition to this, in 2016 Czech consumers spent on average only $€ 9$ a year on organic food, which is very low compared to other EU countries. In neighbouring Austria, the average is nearer $€ 177, € 116$ in Germany, $€ 52$ in Belgium, $€ 44$ in Italy and $€ 101$ in France (Willer and Lernoud, 2018). It was also shown that in the Czech market only 1/3 of consumers purchase organic food over the long term, of which only $5 \%$ regularly purchase organic food, which was also shown in a study by Zagata (2012).

In addition, many of the authors mentioned above have mainly dealt with the behaviour of the adult population, which is the main purchasing force. As a result, the behaviour of the younger generation, which will very quickly be of productive age and become the new purchasing force, has received little investigation. In the Czech Republic, it is more obvious, because there has only been one study on the behaviour of this sector (see Zámková and Prokop, 2013). For this reason, we decided to focus our research on identifying the factors behind the consumer behaviour of the younger generation. To distinguish our research, we used the model of TPB, which was used in Czech surroundings only by two studies (although, e.g., Urban, Zvěřinová and Št’astný, 2012 and Zagata, 2012, focus only on adult population). Further, we incorporated additional constructs (moral attitude, health consciousness, and environmental concern) in the TPB same as Yadav and Pathak (2016), who measured its appropriateness in Indian surrounding. Combining both - young generation and extended model of TPB bring crucial information which can potentially be used not only as a basis for further research but will also be useful for organizations with a practical interest in the production, sale and distribution of organic food. 


\section{Theoretical background}

\section{Organic food}

Organic food, which can be defined as: 'food produced without using the conventional inputs of modern, industrial agriculture: pesticides, synthetic fertilizers, sewage sludge, genetically modified organisms (GMOs), irradiation or food additives' (Allen and Albala, 2007), is by law food from ecological farming which seeks not only to cultivate high-quality food, but also protects the environment. In addition to the health and safety requirements, the production and processing of this food have to fulfill the requirements set out in the Council Regulation (EC) no. 834/2007 and also the law on ecological farming in the Czech Republic no. 242/2000 Coll. (eAGRI, 2016). Organic food can also be simply distinguished from conventional food by its special 'euro-leaf' label which has been used for all ecological products produced in the EU since 2010. In addition to this label, there can also be a national logo, which falls under the competence of the appropriate country (eAGRI, 2017).

\section{Theory of Planned Behaviour (TPB)}

In our research, we examined consumer behaviour using the Theory of Planned Behaviour (TPB), which is considered to be one of the most successful and frequently used models for predicting consumer behaviour (Dowd and Burke, 2013). The Theory of Planned Behaviour assumes that the consumer behaves in a specific way if this behaviour is motivated by a specific intention. Dowd and Burke (2013) consider a direct determinant to be a specific action, and this is defined as the function of three variables personal attitude, subjective norms and the conscious control of behaviour (Zagata, 2012).

The applicability of TPB for organic food has also been demonstrated by several studies across diverse cultures (Yadav and Pathak, 2016), while recent research has shown that other factors also have an important influence. Amongst those which are cited most frequently are moral aspects (Yazdanpanah and Forouzani, 2015, Arvola et al. 2008), health concerns (Smith and Paladino, 2010, Yadav and Pathak, 2016) and concerns about the environment (Smith and Paladino, 2010; Pagiaslis and Krontalis, 2014). Additionally, it has also been shown that the inclusion of other prognostic variables into the original model improves its predictive ability, which is particularly desirable (Arvola et al., 2008; Donald, Cooper and Conchie, 2014).

If we include for organic food, the individual factors can be described in the following way. We understand personal attitude to mean the extent to which the consumer thinks that organic food is healthier, tastier and of better quality, and the extent to which the purchase of organic food is considered to be wise and sensible behaviour (Hughner et al 2007; Gil and Söder 2006; Aryal et al. 2009). Subjective norms refer to whether those close to the consumer (family, friends, colleagues) believe that a specific behaviour is correct and that the consumer should, therefore, also behave in that way (Chen, 2007). Conscious control of behaviour represents the higher price, accessibility and the trust of consumers in the certification system and the label 'organic'. In other words, this varia- 
ble tells us how easy it is for the specific consumer to purchase organic food (Yadav and Pathak, 2016; Yazdanpanah and Forouzani, 2015). We understand the moral aspects to be the concerns of the specific consumer about him/herself, as well as society and the environment (Arvola et al., 2008; Yadava and Pathaka, 2016). Concerns about your own health are the extent to which health and the content of food are important for the consumer when deciding whether or not to buy organic food. In the case of concerns about the environment, it is about the extent to which ecological issues enter into the consumer's decision-making process - when purchasing organic food, do they consider the negative impacts from its production and distribution on the environment? (Yadav and Pathak, 2016).

If we include the above-mentioned factors in the original TPB model, we obtain the following model (see figure 1).

Figure 1. Expanding the Theory of Planned behaviour

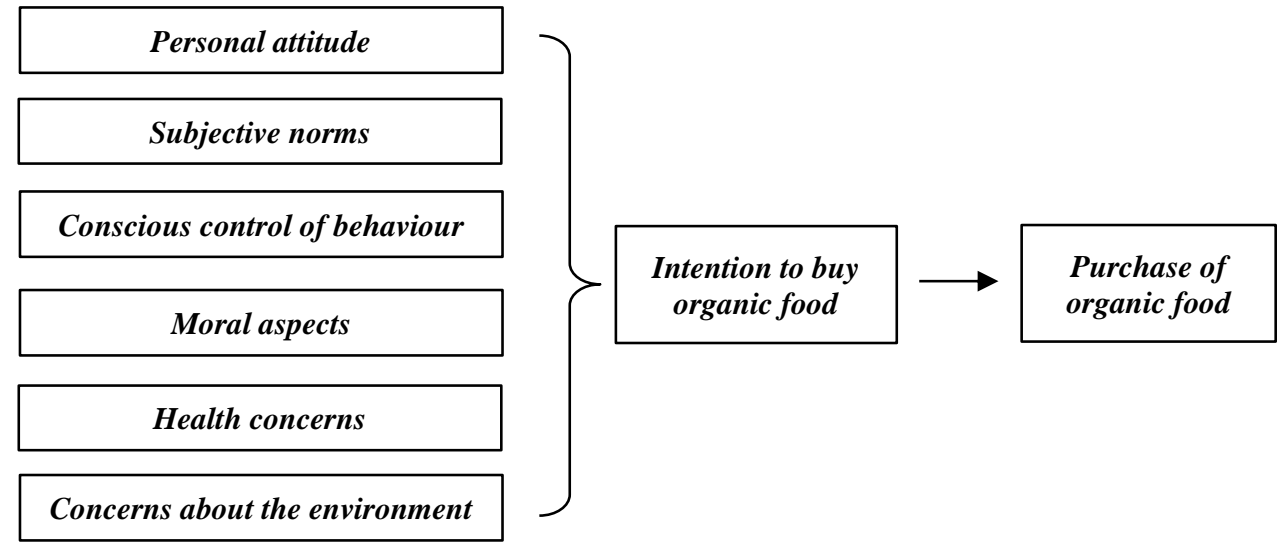

Source: Author, based on Ajzen (2015) and Yadav and Pathak (2016)

\section{Methodology and sampling}

\section{Research objective and data collection}

Our research focuses on the key factors influencing the behaviour of young consumers when deciding to purchase organic food. On the basis of our study of the literature, the research objective was formulated in the following question: 'What are the key factors affecting the behaviour of the young consumer when deciding to purchase organic food?' The discovery of these factors will not only help food suppliers and producers to improve the focus of their marketing, but it will also help us to understand the behaviour of the young consumer better and, therefore, customize their products.

The answer to the research question was sought using the subfactors identified in the literature search related to TPB (see Appendix A). These factors were examined using a quantitative investigation, specifically a self-administered questionnaire. The questionnaire contained 30-32 questions, both open and closed, and the overall number differed 
according to whether or not the consumer purchased organic food. Particular items were measured using a 6-point Likert's scale, where 1 represented a negative attitude (completely disagree or definitely not) and 6 a positive attitude (completely agree or definitely yes). The authors opted for an even Likert scale in order to avoid the middle value and thus obtained the real opinion of the consumer who had to select one of the possibilities and thus adopt a position on the research issue. The data was collected throughout March 2017 using the click4survey online platform. To gain a high number of respondents, the questionnaire was spread through Facebook, which is the most used social network of young consumers (Erge, 2015), by using snowball methods. Moreover, to maintain representativeness of our sample, the questionnaire was placed in 20 Facebook group representing different studying field of students (humanities, natural sciences, and technical/engineering field).

\section{Sampling procedure}

The questionnaire was issued to a sample of 403 university-educated students aged 1832 across Brno's three largest universities - Masaryk University (MU), the University of Technology (VUT) and Mendel University (MENDELU), which represent $60 \%$ return rate. This city was chosen for two reasons. Firstly, it is the second biggest city in the Czech Republic, secondly, it is located in the South Moravia region, which is the biggest organic food market (Hrabalová, 2016). There was a deliberate focus on young consumers because one feature of the younger generation (represented mainly by students) is their concern for the environment and a healthy lifestyle, and they will soon be of productive age and the new purchasing force (Yadav and Pathak, 2016). Moreover, based on results of the survey focused on overall Czech population the organic food is the most frequently purchased by consumers belonging to age bracket $25-44$, especially by women and highly educated consumers (Póč, 2006). Comparing these findings with our sample represented by age bracket 18-32, we consider it to be representative enough for analyzing behaviour of potential buyers as respondents in our sample will match the age of the most frequent buyers in a decade. Additionally, all respondents are highly educated and $77.5 \%$ of them are women, which matches the profile of organic food buyers.

Moreover, the respondents were also divided according to whether or not they purchased organic food. Of the overall number, $41.5 \%$ purchased organic food and $58.5 \%$ preferred conventional food. We deliberately included both groups of consumers purchasing and non-purchasing - in the research sample. The main reason for this decision was the fact that in order to explain people's intentions and discover the relevant key factors influencing the consumer's decision-making process, it was necessary to know the opinions of all the consumers, i.e. both those who purchase organic food and those who do not, as the fact that a consumer does not buy organic food does not necessarily mean that they do not consume it. Table 1 contains the demographic characteristics of the final research sample. 
Table 1. Demographic data from the research sample

Demographic data

\section{$\mathrm{N}$}

Age

$18-22$

23-27

27-32

Gender

Male

Female

Type of study

Bachelor's

Master's

Doctoral

Work status

Full-time

Part-time

Temporary

Not working

Self-employed

Monthly income

Less than 5,000 CZK

$5,001-10,000 \mathrm{CZK}$

$10,001-20,000 \mathrm{CZK}$

$20,001-30,000 \mathrm{CZK}$

30,001 - 50,000 CZK

$50,001 \mathrm{CZK}$ and more

239

140

11

61.6

Source: Authors

\section{Measuring techniques}

A multiple regression analysis was chosen to discover the most important factors in consumer behaviour. Before using it, we verify the internal consistency of the data using Cronbach's alfa. We also run Breusch-Pagan to check for heteroskedasticity in each model. All tests' p-values were lower than $5 \%$ level of significance indicating fulfillment of this regression analysis prerequisite. Moreover, we test for multicollinearity in all our models. The variance inflation factors (VIFs) are well below 10, which indicate no problem with multicollinearity. In order to discover the influence of the other variables and to analyze the data in depth, we also used correlation, a t-test for two independent selections and descriptive statistics. The data was subsequently processed and tested using the SPSS Statistic 23 statistical programme 


\section{Results}

\section{Measurement model}

First, we tested the expanded the TPB model and examined the influence of the individual factors on the consumer's intention to purchase organic food. After multiple regression analysis, independent variables were used to explain 52.3\% (Adjusted R2 $=0,523$ ) of the dependent variables (Table 2). Personal attitude $(\beta=0,086 ; \mathrm{t}=2.122 ; \mathrm{p}<0.05)$, subjective norms $(\beta=0.154 ; \mathrm{t}=4.250 ; \mathrm{p}<0.05)$, health concerns $(\beta=0.175 ; \mathrm{t}=4.676 ; \mathrm{p}$ $<0.05)$, moral aspects $(\beta=0.463 ; \mathrm{t}=7.743 ; \mathrm{p}<0.05)$ were shown to be relevant in explaining the intention of the consumer to purchase organic food, unlike environmental concerns $(\beta=0.076 ; \mathrm{t}=1.929 ; \mathrm{p}>0.05)$ and conscious control of behaviour $(\beta=0.065 ; \mathrm{t}$ $=1.160 ; \mathrm{p}>0.05)$, where no significance was shown.

\section{Table 2. Results of the regression model}

Regression model

Dependent variable: Purchase Intention

$\mathrm{R} 2=0.523$

\begin{tabular}{lccc}
\hline $\begin{array}{l}\text { Independent } \\
\text { variable }\end{array}$ & Beta $(\beta)$ & $\mathrm{t}$ & $\begin{array}{c}\text { Significance } \\
(\mathrm{p} \text {-value) }\end{array}$ \\
\hline Personal attitude & .086 & 2.122 & $.034^{*}$ \\
$\quad$ Health benefits & .043 & .692 & .490 \\
$\quad$ Quality & -.065 & -.997 & .319 \\
$\quad$ Better flavour & .155 & 3.148 & $.002^{*}$ \\
$\quad$ Better environmental protection & .022 & -.391 & .696 \\
$\quad$ Animal welfare considerations & -.080 & -1.544 & .123 \\
$\quad$ Fresher & .096 & 2.091 & $.037^{* *}$ \\
Subjective norms & .154 & 4.250 & $.000^{* *}$ \\
$\quad$ Family members & .187 & 4.853 & $.000^{* *}$ \\
$\quad$ Close friends & .026 & .690 & .491 \\
$\quad$ Colleagues (fellow students) & .052 & 1.335 & .183 \\
Conscious control of behaviour & .076 & 1.929 & .054 \\
Health concerns & .175 & 4.676 & $.000^{* *}$ \\
$\quad$ Interest in product ingredients & .175 & 4.676 & $.000^{* *}$ \\
Environmental concerns & .065 & 1.160 & .247 \\
Moral aspects & .463 & 7.743 & $.000^{* *}$ \\
$\quad$ Better conditions for future generations & .124 & 1.766 & .078 \\
$\quad$ The morally correct option & .332 & 6.397 & $.000^{* *}$ \\
\hline SOUr & & &
\end{tabular}

Source: Authors

\section{Predicting the intentions and behaviour of consumers}

Although personal attitude was statistically the least significant factor, better flavour $(\beta=0.155 ; \mathrm{t}=3.148 ; \mathrm{p}<0,05)$ and food freshness $(\beta=0.096 ; \mathrm{t}=2.091 ; \mathrm{p}<0.05)$ were shown to be the most important attributes influencing the decision-making of the young consumer. Subjective norms were also shown to be a significant predictor of the consumer's intention to purchase organic food, even though a significant influence was only found with family members $(\beta=0.187 ; \mathrm{t}=4.853 ; \mathrm{p}<0.05)$. Another significant factor was health concerns, specifically the consumer's interest in the ingredients of the 
food $(\beta=0.175 ; \mathrm{t}=4.676 ; \mathrm{p}<0.01)$. The final relevant, and at the same time most significant predictor of the consumer's intention, was moral aspects, where young consumers consider the purchase of organic food as the morally correct option $(\beta=0.463 ; \mathrm{t}=$ 4.676; $\mathrm{p}<0.01$ ), and after a content analysis it was even discovered that $58.4 \%$ of respondents associate the purchase of organic food with positive feelings, $7.4 \%$ with mixed feelings, $18.2 \%$ have neutral feelings and $16 \%$ have negative feelings.

Table 3. Descriptive statistics of all factors and subfactors

\begin{tabular}{|c|c|c|c|c|c|c|c|c|}
\hline & \multicolumn{4}{|c|}{$\begin{array}{c}\text { Non- } \\
\text { purchasing }\end{array}$} & \multicolumn{2}{|c|}{ Man } & \multicolumn{2}{|c|}{ Woman } \\
\hline & Mean & SD & Mean & SD & Mean & SD & Mean & SD \\
\hline Healthier & 4.370 & 1.3600 & 3.627 & 1.3494 & 3.816 & 1.4669 & 3.970 & 1.3819 \\
\hline Better quality & 4.667 & 1.2560 & 3.781 & 1.3456 & 3.966 & 1.4179 & 4.201 & 1.3650 \\
\hline Better flavour & 4.105 & 1.3403 & 3.022 & 1.2182 & 3.356 & 1.2757 & 3.505 & 1.4045 \\
\hline $\begin{array}{l}\text { Better environmental } \\
\text { protection }\end{array}$ & 4.846 & 1.3447 & 3.908 & 1.4065 & 3.885 & 1.4661 & 4.416 & 1.4324 \\
\hline $\begin{array}{l}\text { Animal welfare } \\
\text { considerations }\end{array}$ & 4.698 & 1.4493 & 3.873 & 1.4006 & 3.770 & 1.4683 & 4.343 & 1.4561 \\
\hline Freshness & 3.975 & 1.4315 & 3.355 & 1.3278 & 3.425 & 1.4677 & 3.667 & 1.3826 \\
\hline $\begin{array}{l}\text { Opinion of family } \\
\text { members }\end{array}$ & 3.185 & 1.4064 & 2.127 & 1.1093 & 2.561 & 1.3552 & 2.586 & 1.3167 \\
\hline Close friends & 3.185 & 1.4064 & 3.715 & 1.4396 & 3.287 & 1.3969 & 3.660 & 1.3544 \\
\hline $\begin{array}{l}\text { Colleagues (fellow } \\
\text { students) }\end{array}$ & 3.710 & 1.0135 & 3.154 & .9791 & 3.184 & 1.0402 & 3.442 & 1.0209 \\
\hline$\%$ higher price & 2.951 & 1.2940 & 2.259 & .9928 & 2.644 & 1.1908 & 2.518 & 1.1732 \\
\hline Certification system & 3.969 & 1.1552 & 3.943 & 1.3312 & 3.885 & 1.4095 & 3.974 & 1.2150 \\
\hline Interest in health & 4.926 & 1.1287 & 3.855 & 1.4177 & 4.333 & 1.4601 & 4.290 & 1.3935 \\
\hline $\begin{array}{l}\text { It harms the envi- } \\
\text { ronment }\end{array}$ & 5.463 & .8498 & 5.206 & .9556 & 5.207 & .9540 & 5.343 & .9104 \\
\hline $\begin{array}{l}\text { Better lifestyle con- } \\
\text { ditions }\end{array}$ & 4.389 & 1.0588 & 3.180 & 1.3168 & 3.287 & 1.4540 & 3.795 & 1.3037 \\
\hline Future generations & 4.296 & 1.1577 & 3.145 & 1.3278 & 3.195 & 1.5238 & 3.746 & 1.3140 \\
\hline $\begin{array}{l}\text { Morally correct } \\
\text { option }\end{array}$ & 4.340 & 1.2618 & 3.057 & 1.3246 & 3.207 & 1.3394 & 3.700 & 1.4554 \\
\hline
\end{tabular}

Source: Authors

In relation to the insignificance of conscious control of behaviour, it was discovered that young consumers are willing to pay far higher prices for good-quality food, as a result of which the high price no longer acts as one of the main barriers in the purchase of organic food. $90 \%$ (351) of respondents were willing to pay a higher price. It was also discovered that the greater the concerns the consumer had about the environment, the more the ecological aspect of purchasing organic food became important. Based on a correlation coefficient, the strength of this relationship was indicated as a medium strong to significant $(r=0.42 ; \mathrm{p}<0.01)$. 


\section{Discussion}

As part of the research, we looked for an answer to the research question: "What are the key factors influencing the behaviour of students from Brno when deciding to purchase organic food?" We used an expanded TPB model to explain consumer behaviour and as a result, could explain $52 \%$ of the data variability. In the Czech Republic, the students from Brno are influenced by several factors. One of those is personal attitude, the significance of which corresponded with the results from international studies (Yadav and Pathak, 2016; Smith and Paladino, 2010; Yazdanpanah and Forouzani, 2015; Arvola et al., 2008), as well as those which had been carried out in the Czech Republic (Urban, Zvěřinová and Ščasný, 2011; Zagata, 2012). Despite the fact that the value of the standardized beta coefficient indicated a very weak dependence, the positive attitude of students from Brno towards organic food is a good predictor of their actual purchases (Yazdanpanah and Forouzani, 2015). However, Smith and Paladino (2010) state that positive intentions do not necessarily mean actual purchasing. One reason may be the fact that students still live at home, where they do not have the deciding say on which food to buy (Magnusson et al., 2001).

Another factor which the research results in consumer behaviour indicated were significantly influential was subjective norms. Ajzen (1991) stated that people as social beings are easily influenced by their surroundings, in particular by the members of their family, close friends, and colleagues. Therefore, when the consumer is making decisions about their behaviour, they take into consideration the opinions of these people and imagine how they would act under similar circumstances. Our research also showed the important influence of subjective norms where the value of the standardized beta coefficient indicated a weak to medium dependence. Zagata (2012) also arrived at the same conclusion and explained that in the case of the Czech consumer, decisions concerning purchases involve other members of the family who indirectly influence the end behaviour of the consumer. There was a similar explanation from Zvěřinová Urban, Ščastný (2011), who stated that the Czech consumer, described as having a lack of information, relies on the opinions of other people who they trust and who they imagine have greater experience. This finding led us to the conclusion that this might also be the case for the young consumer. The above research also showed that organic food is viewed negatively by the families of consumers who do not buy organic food as well as by those who prioritize it. From this, we deduced that there may be a limited level of independence in the decision-making of students from Brno, which may be one of the main reasons why a large number of young consumers still prefer conventional food.

Regarding conscious control of behaviour, no significant influence on the intentions of students from Brno to purchase organic food was demonstrated. Despite the fact that these results go against Ajzen's theory, this is not so surprising in the case of purchasing organic food. The same results were also corroborated by a number of other authors (Yazdanpanah and Forouzani, 2015; Tarkiainen and Sundqvist, 2005) and Urban, Zvěřinová and Ščastný (2012) in the case of the Czech consumer. One possible explanation for this may be the fact that the consumer is used to the higher costs associated with the purchase of organic food and already expects premium prices. Our results also corroborate this explanation as $90 \%$ of the respondents stated that they were willing to pay $10 \%-20 \%$ higher prices for organic food than for conventional food. Another possible explanation could be the important influence of the surroundings, as was shown by its 
statistical significance in the research where consumers behaved in a way that was influenced by the people around them. However, we believe we can only speculate on these results and further research is required to better understand the influence of this variable.

Despite the repeated success of TPB in predicting people's behaviour, the results from recent studies show that in order to increase its predictive value, further variables have to be added to the original model. One of those was health concerns, which was added to the original model by Yadav and Pathak (2016) as a result of consumers' growing interest in health and healthy lifestyles when the health factor gradually came to be recognized as an important parameter in purchase decision-making. The importance of this factor was also demonstrated in this research, where the basic value of the standardized beta coefficient was indicated as a low to the medium association. This conclusion was also arrived at by Squires et al. (2001), who confirmed that the more the consumer is interested in his/her health, the more willing they are to buy organic food. Over recent years we have witnessed the rising trend in healthy lifestyles, where product ingredients and their products have become key factors when deciding on food purchases, therefore, the inclusion of this factor in the original model is highly desirable. In relation to this, Lea and Worsley (2005) correctly pointed out that as a result of this, organic food is generally regarded as healthier and is purchased either by consumers who believe in its beneficial health effects or by people who suffer from health problems. Although it is rare to find young consumers with serious health problems, the statistical significance of this subfactor was not confirmed in this research, though this would not have to be the case with other research samples containing older generations.

Another factor which Yadav and Pathak (2016) considered to be significant was concerns about the environment. This was based on the assumption that rising demand for organic food was the result of consumers' growing interest in ecological issues, which was reflected in the decision-making process when purchasing organic food. However, this was not shown to be statistically significant in this research. This conclusion was also reached in previous research (Yadav and Pathak, 2016; Smith and Paladino, 2010), where the authors explained this fact either through a low level of altruism or the inability of consumers to modify their opinions into new patterns of behaviour. Based on our findings concerning Czech consumers, we lean more towards the second interpretation, as a strong to the substantial association was discovered between personal attitude and concerns about the environment. We can infer from this that the Czech consumer has not yet managed to fully absorb their new opinions.

The last factor which was added to the original TPB model, and the significance of which is agreed upon by a number of authors (Yadav and Pathak, 2016; Yazdanpanah and Forouzani, 2015; Arvola et al., 2008; Dean et al., 2008), was moral aspects. Its significance stems from criticisms of rational models and represents people's convictions about what is and is not correct. The significance of this factor in predicting the consumer's intention to purchase organic food was also demonstrated in this research and the value of the standardized beta coefficient indicated the most substantial association in comparison with the other factors. This conclusion was also reached by Yazdanpanah and Forouzani (2015) who stated that young consumers consider the purchase of organic food to be the morally correct option, bringing them a feeling of inner satisfaction. It is also for this reason that Arvola et al. (2008) and Thørgersen (2002) 
believe that it is desirable to include moral aspects in the original TPB model. In addition, the results from our study also confirmed that students from Brno have mainly positive associations with the purchase of organic food (58.4\%), including the feeling of acting responsibly, which also coincides with the findings from the above-mentioned research.

\section{Research limitations and conclusions}

Our use of the social-psychological TPB model to explain the behaviour of young Czech consumers when purchasing organic food brought us some interesting conclusions. It transpired that the most important factors were moral aspects and health concerns, which reinforces the results of previous research which pointed to the important influence of other variables. On the other hand, the influence of conscious control of behaviour was shown to be insignificant, which corresponds to the trend in healthy living and the result that consumers are willing to pay higher prices for organic food.

It is clear from the above that organic producers, distributors, and retailers of organic food should focus on the moral and health aspects, better taste and freshness of organic food when promoting organic food, in other words, those which most importantly affect them when deciding to buy or nor organic food. Likewise, producers, distributor, and retailer don't have to be afraid to reflect the quality of organic food in the total price, which arise from our findings. The study shows that the young generation of Brno students is willing to pay an extra charge for the quality, freshness and better taste of organic food. Moreover, in the case of its purchase, they appreciate information about the positive moral and health aspects of this type of purchase. A good example can be freely available deep litter farm eggs, chemically untreated fruit and vegetables and livestock products from organic farming, which are more and more demanded by Czech consumers (Hrabalová, Šejnohová, 2015).

Despite the interesting results which the research brought, the study has its limitations. One of these was the fact that in our questionnaire we were interested in how the consumer viewed the purchase of organic food in general and not how they view the purchase of individual organic products. Since recent studies have shown that consumers' perception differs according to the type of organic product purchased, future research could focus on the purchase of specific organic products. We also realize that the research may be limited by the fact that the questionnaire was aimed solely at the younger generation of consumers studying in Brno, the second largest city in the Czech Republic. As a result, the conclusions of the research cannot be generalized to include the overall population of young consumers living in the Czech Republic. It was also impossible to test the influence of education due to the choice of research sample which the authors decided to focus on. 
Acknowledgments: The research is supported by the Masaryk University research project MUNI/A/1054/2018 Consumer behaviour in the context of the circular economy.

Disclosure statement: No potential conflict of interest was reported by the authors.

\section{References}

AHMED, R., \& RAHMAN, K. (2015). Understanding the consumer behaviour towards organic food: a study of the Bangladesh market. IOSR Journal of Business and Management, 17(4), 49-64. DOI: $10.9790 / 487 \mathrm{X}-17464964$

ALLEN, G. J., \& ALBALA, K. (Eds.). (2007). The business of food: encyclopedia of the food and drink industries. Conn.: Greenwood Press. ISBN 03-133-3725-X

AJZEN, I. (1991). The theory of planned behavior. Organizational behavior and human decision processes, 50(2), 179-211.DOI: 10.1016/0749-5978(91)90020-T

AJZEN, I. (2015). Consumer attitudes and behavior: the theory of planned behavior applied to food consumption decisions. Italian Review of Agricultural Economics, 70(2), 121-138. DOI: $10.13128 /$ REA-18003

ARMITAGE, C. J., \& Conner, M. (2001). Efficacy of the theory of planned behaviour: A meta-analytic review. British journal of social psychology, 40(4), 471-499. DOI: $\underline{10.1348 / 014466601164939}$

ARVOLA, A., VASSALlO, M., DEAN, M., LAMPILA, P., SABA, A., LÄHTEENMÄKI, L., \& SHEPHERD, R. (2008). Predicting intentions to purchase organic food: The role of affective and moral attitudes in the Theory of Planned Behaviour. Appetite, 50(2-3), 443-454. DOI: 10.1016/j.appet.2007.09.010

ARYAL, K. P., CHAUDHARY, P., PANDIT, S., \& SHARMA, G. (2009). Consumers' willingness to pay for organic products: a case from Kathmandu valley. Journal of Agriculture and Environment, 10, 15-26. DOI: 10.3126/aej.v10i0.2126

CHEN, M. F. (2007). Consumer attitudes and purchase intentions in relation to organic foods in Taiwan: Moderating effects of food-related personality traits. Food Quality and preference, 18(7), 1008-1021. DOI: 10.1016/j.foodqual.2007.04.004

DEAN, M., RAATS, M. M., \& SHEPHERD, R. (2008). Moral Concerns and Consumer Choice of Fresh and Processed Organic Foods 1. Journal of Applied Social Psychology, 38(8), 2088-2107. DOI: 10.1111/j.1559-1816.2008.00382.x

DONALD, I. J., COOPER, S. R., \& CONCHIE, S. M. (2014). An extended theory of planned behaviour model of the psychological factors affecting commuters' transport mode use. Journal of environmental psychology,40, 39-48. DOI: 10.1016/j.jenvp.2014.03.003

DOWD, K., \& BURKE, K. J. (2013). The influence of ethical values and food choice motivations on intentions to purchase sustainably sourced foods. Appetite, 69, 137-144. DOI: $10.1016 /$ j.appet.2013.05.024 
EAGRI (2016). Aktuální témata. Biopotraviny [online]. Ministerstvo zemědělství. [cit. 2017-01-07]. Retrieved from: http://eagri.cz/public/web/mze/zemedelstvi/ekologickezemedelstvi/biopotraviny/

EAGRI. (2017). Ministerstvo zemědělství. Loga pro ekologické zemědělství. [online]. Ministerstvo zemědělství. [cit. 2017-01-07]. Retrieved from: http://eagri.cz/public/web/mze/zemedelstvi/ekologicke-zemedelstvi/loga-a-znaceni/

EFFENDI, I., Ginting, P., LUBIS, A. N., \& FACHRUDDIN, K. A. (2015). Analysis of consumer behavior of organic food in North Sumatra Province, Indonesia. Journal of Business and Management, 4(1), 44-58. DOI. 10.12735/jbm.v4i1p44

EGER, L. (2015). Is Facebook a similar learning tool for university students as LMS?. Procedia-Social and Behavioral Sciences, 203, 233-238. DOI: 10.1016/j.sbspro.2015.08.287

FiBL. (2014). Media release. European organic market continued to grow in 2014. [online]. Ifoam-eu. [cit. 2017-01-20]. Retrieved from: http://www.ifoameu.org/sites/default/files/fiblifoameuami_policy_cap_press_release_organic data_20160210.pdf

FRÝDLOVÁ, M., \& VOSTRÁ, H. (2014). Determinants influencing consumer behaviour in organic food market. Acta Universitatis Agriculturae et Silviculturae Mendelianae Brunensis, 59(7), 111-120. DOI: 10.11118/actaun201159070111

GIL, J. M., \& SOLER, F. (2006). Knowledge and willingness to pay for organic food in Spain: Evidence from experimental auctions. Acta Agriculturae Scand Section C, 3(3-4), 109-124. DOI: $10.1080 / 16507540601127656$

HRABALOVÁ, A., ŠEJNOHOVÁ, H. (2015). Prezentace. Statistika a trendy vývoje ekologického zemédělství v ČR. [online]. Konference Biosummit. [cit. 2017-01-20]. Retrieved from: https://www.techsciresearch.com/report/global-organic-food-marketforecast-and-opportunities-2020/450.html

HRABALOVÁ A. (2016). Zprávy. Ekologické zemédělství a biopotraviny v ČR. [online]. bio-info. [cit. 2017-01-20]. Retrieved from: http://www.bioinfo.cz/zpravy/ekologicke-zemedelstvi-a-biopotraviny-v-cr

HUGHNER, R. S., MCDONAGH, P., PROTHERO, A., SHULTZ, C. J., \& STANTON, J. (2007). Who are organic food consumers? A compilation and review of why people purchase organic food. Journal of Consumer Behaviour: An International Research Review, 6(2- 3), 94-110. DOI: 10.1002/cb.210

LEA, E., \& WORSLEY, T. (2005). Australians' organic food beliefs, demographics and values. British food journal, 107(11), 855-869. DOI: $10.1108 / 00070700510629797$

MAGNUSSON, M. K., ARVOLA, A., KOIVISTO HURSTI, U. K., ÅBERG, L., \& SJÖDÉN, P. O. (2001). Attitudes towards organic foods among Swedish consumers. British food journal, 103(3), 209-227. DOI: $10.1108 / 00070700110386755$

MAKATOUNI, A. (2002). What motivates consumers to buy organic food in the UK? Results from a qualitative study. British Food Journal, 104(3/4/5), 345-352. DOI: $\underline{10.1108 / 00070700210425769}$ 
PAGIASLIS, A., \& KRONTALIS, A. K. (2014). Green consumption behavior antecedents: Environmental concern, knowledge, and beliefs. Psychology \& Marketing, 31(5), 335-348. DOI: 10.1002/mar.20698

PÓČ I. (2006). Prezentace. Potenciál BIO potravin na českém trhu - Marketingová studie. [online]. slideplayer. [cit. 2019-02-20]. Retrieved from: https://slideplayer.cz/slide/12267024/

SMITH, S., \& PALADINO, A. (2010). Eating clean and green? Investigating consumer motivations towards the purchase of organic food. Australasian Marketing Journal (AMJ), 18(2), 93-104. DOI: 10.1016/j.ausmj.2010.01.001

SQUIRES, L., JURIC, B., \& BETTINA CORNWELL, T. (2001). Level of market development and intensity of organic food consumption: cross-cultural study of Danish and New Zealand consumers. Journal of Consumer Marketing, 18(5), 392-409. DOI: $\underline{10.1108 / 07363760110398754}$

SUH, B. W., EVES, A., \& LUMBERS, M. (2012). Consumers' Attitude and Understanding of Organic Food: The Case of South Korea. Journal of foodservice business research, 15(1), 49-63. DOI: 10.1080/15378020.2012.650524

ŠÁNOVÁ, P. (2008). Zkrácený článek. Biopotraviny - aktuální trend ve spotřebě potravin. [online]. Česká společnost pro jakost. [cit. 2017-01-07]. Retrieved from:

https://www.csq.cz/12007/?tx_ttnews\%5Btt_news\%5D=802\&cHash=22cab62acc90c07 de2f74a0a57db4fb7

ŠČASNÝ, M., URBAN, J., \& ZVĚŘINOVÁ, I. (2013). Environmentally significant behaviour in the Czech Republic: Energy, food and transportation. Karolinum Press. ISBN: 9788024620763

TARKIAINEN, A., \& SUNDQVIST, S. (2005). Subjective norms, attitudes and intentions of Finnish consumers in buying organic food. British food journal, 107(11), 808822. DOI: $10.1108 / 00070700510629760$

TECHSCI RESEARCH. (2015). Report. Global Organic Food Market Forecast and Opportunities, 2020 [online]. TechSci Research. [cit. 2017-01-20]. Retrieved from: https://www.techsciresearch.com/report/global-organic-food-market-forecast-andopportunities-2020/450.html

THØGERSEN, J. (2002). Direct experience and the strength of the personal normbehavior relationship. Psychology \& Marketing, 19(10), 881-893. DOI:

10.1002/mar.10042

UBRAN, J. A. N., ZVĚŘINOVÁ, I., \& ŠČASNÝ, M. (2012). What motivates Czech consumers to buy organic food?. Sociologicky casopis, 48(3), 709.

VOON, J. P., NGUI, K. S., \& AGRAWAL, A. (2011). Determinants of willingness to purchase organic food: An exploratory study using structural equation modeling.

WILLER, H., \& LERNOUD, J. (2018). The world of organic agriculture: statistics and emerging trends 2018. Research Institute of Organic Agriculture FiBL, IFOAM - Organics International. 
YADAV, R., \& PATHAK, G. S. (2016). Intention to purchase organic food among young consumers: Evidences from a developing nation. Appetite, 96, 122-128. DOI: 10.1016/j.appet.2015.09.017

YAZDANPANAH, M., \& FOROUZANI, M. (2015). Application of the Theory of Planned Behaviour to predict Iranian students' intention to purchase organic food. Journal of Cleaner Production, 107, 342-352. DOI: 10.1016/j.jclepro.2015.02.071

ZAGATA, L. (2012). Consumers' beliefs and behavioural intentions towards organic food. Evidence from the Czech Republic. Appetite, 59(1), 81-89. DOI: 10.1016/j.appet.2012.03.023

ZÁMKOVÁ, M., \& PROKOP, M. (2013). Consumers behaviour of students when shopping for organic food in the Czech Republic. Acta Universitatis Agriculturae et Silviculturae Mendelianae Brunensis, 61(4), 1191-1201. DOI: $\underline{10.11118 / \operatorname{actaun} 201361041191}$

ZVĚŘINOVÁ, I., URBAN, J., \& ŠČASNÝ, M. (2011). Why do Czech consumers purchase organic food?. In: Prague: 3 rd Scientific Conference.

ŽIVĚLOVÁ, I., \& CRHOVÁ, M. (2013). Organic food market in the Czech Republic. Acta Universitatis Agriculturae et Silviculturae Mendelianae Brunensis, 61(2), 539546. DOI: $\underline{10.11118 / \text { actaun201361020539 }}$ 


\section{Appendix}

\section{A. Questionnaire items and their source of adoption.}

\begin{tabular}{|c|c|c|}
\hline Variables & Measuring items & $\begin{array}{l}\text { Source from } \\
\text { adoption }\end{array}$ \\
\hline Attitude & $\begin{array}{l}\text { 1. I consider organic food as healthier than con- } \\
\text { ventional foods. } \\
\text { 2. I consider organic food as having better quality } \\
\text { than conventional foods. } \\
\text { 3. I consider organic food as tastier than conven- } \\
\text { tional foods. } \\
\text { 4. I consider organic food as environmentally } \\
\text { friendlier than conventional foods. } \\
\text { 5. I consider organic food as environmentally } \\
\text { friendlier than conventional foods. } \\
\text { 6. I consider organic food as more supportive } \\
\text { animal welfare than conventional foods. } \\
\text { 7. I consider organic food as fresher than conven- } \\
\text { tional foods. }\end{array}$ & Zagata (2012) \\
\hline Subjective norms & $\begin{array}{l}\text { 1. Members of my family consider consumption } \\
\text { and thus purchase organic food as important. } \\
\text { 2. My close friends consider organic food as an } \\
\text { advertising trick. } \\
\text { 3. Colleagues consider purchase of organic food } \\
\text { as a good thing. }\end{array}$ & $\begin{array}{l}\text { Zagata }(2012) \\
\text { Yazdanpanah a } \\
\text { Forouzani } \\
(2015)\end{array}$ \\
\hline $\begin{array}{l}\text { Perceived behavioral } \\
\text { control }\end{array}$ & $\begin{array}{l}\text { 1. How much higher price are you willing to pay } \\
\text { for organic food compared to conventional } \\
\text { food? } \\
\text { 2. I consider the Czech certification system and } \\
\text { thus the designation of organic food, to be } \\
\text { credible. }\end{array}$ & Zagata (2012) \\
\hline $\begin{array}{l}\text { Environmental con- } \\
\text { cern }\end{array}$ & $\begin{array}{l}\text { 1. Do you think that today's society seriously } \\
\text { damages nature? } \\
\text { 2. Do you think that by purchasing organic food } \\
\text { you contribute to improving living conditions? }\end{array}$ & $\begin{array}{l}\text { Yadav a Pathak } \\
(2016)\end{array}$ \\
\hline Moral aspects & $\begin{array}{l}\text { 1. Buying organic food contributes to better } \\
\text { conditions for future generations. } \\
\text { 2. I consider the purchase of organic food as a } \\
\text { morally correct thing. }\end{array}$ & $\begin{array}{l}\text { Yadav a Pathak } \\
\text { (2016); Arvola } \\
\text { et al. (2008) }\end{array}$ \\
\hline Health consciousness & $\begin{array}{l}\text { 1. You are interested in the ingredients of the } \\
\text { food while shopping? }\end{array}$ & $\begin{array}{l}\text { Yadav a Pathak } \\
(2016)\end{array}$ \\
\hline Intention & $\begin{array}{l}\text { 1. I will prefer organic food to conventional food } \\
\text { when I am shopping organic food next time. }\end{array}$ & $\begin{array}{l}\text { Arvola et al. } \\
\text { (2008), Yadav a } \\
\text { Pathak (2016) }\end{array}$ \\
\hline
\end{tabular}

Source: Authors. 